University of Nebraska - Lincoln

DigitalCommons@University of Nebraska - Lincoln

Roman L. Hruska U.S. Meat Animal Research

U.S. Department of Agriculture: Agricultural Center

Research Service, Lincoln, Nebraska

1982

\title{
Genetic Variation Among and Within Herds of Angus and Hereford Cattle
}

Larry V. Cundiff

U.S. Meat Animal Research Center, Larry.Cundiff@ars.usda.gov

Keith A. Gregory

U.S. Meat Animal Research Center

Follow this and additional works at: https://digitalcommons.unl.edu/hruskareports

Part of the Animal Sciences Commons

Cundiff, Larry V. and Gregory, Keith A., "Genetic Variation Among and Within Herds of Angus and Hereford Cattle" (1982). Roman L. Hruska U.S. Meat Animal Research Center. 15.

https://digitalcommons.unl.edu/hruskareports/15

This Article is brought to you for free and open access by the U.S. Department of Agriculture: Agricultural Research Service, Lincoln, Nebraska at DigitalCommons@University of Nebraska - Lincoln. It has been accepted for inclusion in Roman L. Hruska U.S. Meat Animal Research Center by an authorized administrator of DigitalCommons@University of Nebraska - Lincoln. 


\section{GENETIC VARIATION AMONG AND WITHIN HERDS OF ANGUS AND HEREFORD CATTLE}

\section{Larry V. Cundiff'and Keith E. Gregory}

\section{Introduction}

Historically, beef cattle record of performance programs have by necessity expressed variation as deviations or ratios from herd means because differences between herds are believed to be large primarily because of environment. To the extent differences between herds are genetic, this procedure underestimates or overestimates breeding values of individuals relative to breed average depending on whether they are produced in herds of above or below average genetic merit for a breed. We conducted this study in cooperation with the American Angus Association and the American Polled Hereford Association, and designed it to separate and evaluate the relative importance of between-herd and within-herd sources of genetic variation for birth, growth and carcass characteristics.

\section{Procedure}

Birth and livability data on 995 calves, weaning data on 915 calves, and postweaning growth and carcass data on 817 calves produced in two calf crops were studied. Calves were sired by 51 bulls from 18 Angus herds (2 to 3 sires/ herd) and 44 bulls from 18 Polled Hereford herds ( 2 to 4 sires/herd) through artificial insemination ( $\mathrm{Al}$ ) matings. Semen was provided by the American Angus Association and the American Polled Hereford Association for their respective breeds. The cows were straightbred Angus and Hereford calving as 2- and 3 -year-olds mated to produce straightbred and reciprocal cross calves.

The calving season was from March 4 to May 4 in each year. Calves were creep fed whole oats from July to weaning in late October. After weaning, steer and heifer calves were fed a ration comprised of corn silage, steam flaked corn, dehydrated alfalfa pellets, and a $40 \%$ crude protein supplement ranging in energy density from 1.4 Mcal ME/lb dry matter early in the feeding period to $1.5 \mathrm{Mcal}$ $\mathrm{ME} / \mathrm{lb}$ later in the feeding period. They were fed 229 days in the first year and 299 days in the second year. Carcass data were obtained in a commercial packing plant about $24 \mathrm{hr}$ after slaughter.

\section{Results}

Results indicated that both within and between herd sources of genetic variation significantly influenced growth and carcass traits. Herds were a significant

${ }^{1}$ Larry V. Cundiff is a research leader (Breeding and Genetics) at MARC. source of genetic variation for birth weight, 200-day weaning weight, postweaning average daily gain (ADG), 452day weight, final grade, carcass conformation, and marbling. Sires within herd were a significant source of genetic variation for postweaning ADG, 452-day weight, final carcass grade, carcass conformation, marbling, fat thickness, rib-eye area, and estimated cutability.

Variance components for herds $(H)$, sires within herd (S), and progeny within sires and herd (W) expressed as a percentage of total variance $(\mathrm{H}+\mathrm{S}+\mathrm{W})$ are shown in Table 1. The correlation among breeding value for herd mates $(R)$ and heritability $\left(\mathrm{h}^{2}\right.$, and $\left.\mathrm{h}^{2}{ }_{\mathrm{w}}\right)$ are also presented in Table 1.

Estimates of the correlation between breeding value of sires produced in the same herd $(R)$ ranged from 0.37 to 0.69 for growth traits and from -0.10 to 0.34 for carcass traits. $R$ is expected to be greater than zero only to the extent that genetic diversity exists between herds as a result of (1) extra pedigree likeness among individuals produced in the same herd retative to those in other herds, (2) differential selection pressure and response between herds, (3) random genetic differences between herds that have accrued by chance, or (4) sampling of bulls in this study. The average pedigree relationship of bulls sampled in this experiment was 0.11 in both breeds, and only one-fourth of this, or about 0.03 , is to be reflected in coefficients of $\mathrm{R}$ derived for each trait in this study. Thus, the relatively high coeffi-

Table 1.-Percentage of variance from herds $(H)$, sires/herds $(\mathrm{S})$, and progeny/sires (W); correlation between sires from the same herd (R); and heritability within breed $\left(h_{t}^{2}\right)$ and within herd $\left(h_{w}^{2}\right)$

\begin{tabular}{|c|c|c|c|c|c|c|}
\hline \multirow{3}{*}{ Trait } & \multicolumn{6}{|c|}{ Percentage of total $(\mathrm{H}+\mathrm{S}+\mathrm{W})^{1}$} \\
\hline & $\mathrm{H}$ & $s$ & w & $R$ & $h_{t}^{2}$ & $h_{w}^{2}$ \\
\hline & $(\%)$ & (\%) & (\%) & (\%) & & \\
\hline & \multicolumn{6}{|c|}{$(\%)$} \\
\hline Calving difficulty . . . . . . _. & 1.8 & -1.7 & 99.9 & $\ldots$ & 0 & -7 \\
\hline Birth wt & 3.9 & 2.4 & 93.8 & 62 & 22 & 10 \\
\hline Live-birth & 1.0 & 1.4 & 97.6 & 58 & 10 & 4 \\
\hline Live-72 $\mathrm{hr} \ldots . . . .$. & .9 & 1.5 & 97.7 & 63 & 9 & 4 \\
\hline Live-weaning & 3.3 & 2 & 96.5 & 6 & 14 & 13 \\
\hline ADG, birth-wt . . . . . . & 1.5 & 2.5 & 96.1 & 37 & 15 & 10 \\
\hline 200 day wt & 2.6 & 1.2 & 96.2 & 69 & 14. & 5 \\
\hline ADG wt-fin .................. & 5.6 & 8.0 & 86.4 & 41 & 46 & 34 \\
\hline 452-day wt . . . . . . . . . & 5.2 & 6.5 & 88.3 & 44 & 40 & 27 \\
\hline Final grade & 4.2 & 9.7 & 86.0 & 30 & 50 & 41 \\
\hline Conf. grade & 4.4 & 8.2 & 87.5 & 34 & 44 & 34 \\
\hline Marbling ............... & 4.0 & 10.6 & 85.4 & 28 & 52 & 44 \\
\hline Fat thickness . . . & -.7 & 7.7 & 93.0 & 10 & 28 & 31 \\
\hline Longissimus area . . . . . . . . . . . . & .5 & 8.2 & 91.3 & 6 & 24 & 33 \\
\hline Estimated cutability & 4 & 5.8 & 93.9 & 6 & 24 & 23 \\
\hline
\end{tabular}

$1=1 / 4$ the genetic variance between herds $=\left[1 / 4\left(R V_{G}\right)\right], S=1 / 4$ the genetic variance within herds $=\left[1 / 4(1-R) V_{G}\right], W=3 / 4$ the genetic variance within herds plus environmental variance within herds $=\left[3 / 4(1-R) V_{G}+(1-C) V_{E}\right], R=$ the correlation among breeding values of herd mates $=H /(H+S), h_{t}^{2}=4(H+S) / 4(H+S+W)$, and $h_{w}^{2}=4 S /(S+W)$. cients found for $\mathrm{R}$ indicate that differential selection pressure and response have resulted in substantial genetic diversity beween herds of the Angus and Polled Hereford breeds, especially for growth traits.

$h^{2}$ ) shown in Table 1 pertain to different populations of inference. Tabled figures are shown in percentage. The first estimate $\left(\mathrm{h}^{2} \mathrm{t}\right)$ is expected to apply when sires sampled from a number of herds are progeny tested in the environment of a single herd, or when progeny performance of individual sires can be compared against the refence sires in multiherd national sire evaluation programs. The second estimate $\left(h^{2}{ }_{w}\right)$ applies to closed herds. In herds outcrossing to sires from many and $h^{2}$ w.

Estimates of $\mathrm{h}^{2}$ t were larger than those for $h^{2}{ }_{w}$ in proportion to the influence of herd effects. Extra genetic variation arising from between herd sources increases the effectiveness of sequential selection based first on individual performance of bulls selected within herds and then between herds on the basis of performance relative to closed herd selection or outcrossing with selection based on variation within herds. Rate ference sires are used to identify outstanding sires for wide spread use through Al not only because of increased selection intensity but also because heriated when progeny test scores of the re- 


\begin{abstract}
Continued.
tability is increased by significant between herd genetic variation. Several generations of extensive outcrossing would introduce about half of the between herd genetic variance into a herd and increase heritability and effectiveness of individual selection in subsequent generations. However, accuracy of selection and genetic change during the outcrossing period would be reduced relative to use of progeny tested sires.

Estimates of heritability for percentage calving difficulty and survival were low. The estimates of heritability for survival traits (low, 4 to $14 \%$ ), postweaning growth traits (moderate, 27 to $46 \%$ ), and carcass traits (moderate to high, 23 to $52 \%$ ) compare closely with previous estimates for similar traits. The heritability estimates for preweaning growth tended to be lower in this study (low, 5 to $15 \%$ ) than in previous reports, possibly because all calves were raised by 2 -year-old dams in the first year and by 2 -year-old and 3-year-old dams in the second year, which provide a more limited maternal environment than cows of more mature ages.
\end{abstract}

